\title{
Paenibacillus jamilae sp. nov., an exopolysaccharide-producing bacterium able to grow in olive-mill wastewater
}

\author{
1,2 Department of \\ Microbiology ${ }^{1}$ and \\ Department of \\ Biochemistry and \\ Molecular Biology2, \\ Faculty of Pharmacy, \\ University of Granada, \\ Campus de Cartuja s/n CP \\ 18071, Granada, Spain \\ 3 Department of \\ Microbiology, GBF \\ National Research \\ Institute for \\ Biotechnology, D-38124 \\ Braunschweig, Germany
}

\author{
Margarita Aguilera, ${ }^{1}$ Mercedes Monteoliva-Sánchez, ${ }^{1}$ Antonio Suárez, ${ }^{2}$ \\ Victor Guerra, ${ }^{1}$ Catherine Lizama, ${ }^{1}$ Antonio Bennasar ${ }^{3}$ \\ and Alberto Ramos-Cormenzana ${ }^{1}$
}

Author for correspondence: Mercedes Monteoliva-Sánchez. Tel: +34 958 243875. Fax: +34 958246235. e-mail:mmonteol@platon.ugr.es

\begin{abstract}
Endospore-forming strains were isolated from corn-compost treated with olive-mill wastewater ('alpechín'). The strains were taxonomically studied and proposed as a novel Paenibacillus species. These organisms (strains B. ${ }^{\top}$, B.7 and B.9) were particularly distinguishable from other aerobic spore-forming species by their ability to grow optimally in $100 \%(v / v)$ olive-mill wastewater at $30^{\circ} \mathrm{C}$ and $\mathrm{pH} 7.0$ and concomitant production of an interesting exopolysaccharide. Chemotaxonomic analysis revealed that MK-7 was the predominant menaquinone, the major fatty acid was anteiso $C_{15: 0}$ and the cell wall contained meso-diaminopimelic acid. The DNA G+C content was $40.7 \mathrm{~mol} \%$. Comparative sequence analysis of $16 \mathrm{~S}$ rDNA with different reference species from the genera Bacillus, Paenibacillus, Brevibacillus, Aneurinibacillus, Alicyclobacillus, Halobacillus, Virgibacillus, Amphibacillus, Coprobacillus and Gracilibacillus indicated that the isolated strains were highly related to the genus Paenibacillus. Strain B. ${ }^{\top}$ formed an evolutionary lineage distinct from other species within the evolutionary radiation encompassing the genus Paenibacillus. Strain B. $3^{\top}$ was a close relative of Paenibacillus polymyxa, but DNA-DNA relatedness data with this species was very low (relative binding ratio $<16 \%$ ). Based on the morphological and physiological characteristics, as well as on the phylogenetic position determined by 165 rDNA analysis and DNA-DNA relatedness data, it is concluded that these strains should be designated a novel species, for which the name Paenibacillus jamilae sp. nov. is proposed. The type strain is B. $3^{\top}\left(=\right.$ CECT $5266^{\top}=$ DSM $\left.13815^{\top}\right)$.
\end{abstract}

Keywords: Paenibacillus jamilae sp. nov., olive-mill wastewater, exopolysaccharide, 16S rDNA analysis

\section{INTRODUCTION}

Olive-mill wastewater (OMWW), known as 'alpechín', is a toxic aqueous residue produced in olive oil extraction. The most important olive oil-producing countries are Spain and Italy. Bioremediation of alpechín by using the residue as a culture medium for some micro-organisms can also provide new resources, such as exopolysaccharides (EPSs), which are highly

Abbreviations: EPS, exopolysaccharide; OMWW, olive-mill wastewater; RBR, relative binding ratio.

The GenBank/EMBL/DDBJ accession number for the $16 \mathrm{~S}$ rDNA sequence of strain B. $3^{\top}$ is $J 271157$ interesting biopolymers due to their potential applications (Ramos-Cormenzana et al., 1995). Developments in molecular biological methods have suggested that the genus Bacillus is a phylogenetically heterogeneous taxon. For example, analyses showed a wide range of $\mathrm{G}+\mathrm{C}$ contents (32-69 $\mathrm{mol} \%$ ) among the DNAs of Bacillus species (Claus \& Berkeley, 1986; Slepecky \& Hemphill, 1991; Stackebrandt \& Liesack, 1993). DNA reassociation studies have shown that many Bacillus species are composites of several genetically unrelated species (Priest, 1981; Slepecky \& Hemphill, 1991; Nakamura, 1996; Shida et al., 1997b). Resulting phylogenetic studies by $16 \mathrm{~S}$ rRNA gene sequencing revealed that the genus Bacillus could be 
separated into several phylogenetically distinct genera such as Alicyclobacillus (Wisotzkey et al., 1992), Paenibacillus (Ash et al., 1993), Aneurinibacillus (Shida et al., 1996), Brevibacillus (Shida et al., 1996), Halobacillus (Spring et al., 1996), Gracilibacillus and Salibacillus (Wainø et al., 1999), and Coprobacillus (Kageyama \& Benno, 2000).

In the present study, three strains (B. $3^{\mathrm{T}}$, B.7 and B.9) of Gram-variable, spore-forming bacilli were isolated from a corn-compost treated with OMWW. The strains were able to grow in $100 \%$ (v/v) OMWW and to produce an heteropolysaccharide consisting of fucose, xylose, rhamnose, arabinose, mannose, galactose and glucose as sugar components (V. Guerra, M. Monteoliva-Sánchez, M. Aguilera \& A. RamosCormenzana, unpublished data). This EPS has been shown to enhance the immune response in mice (Ramos-Cormenzana \& Monteoliva-Sánchez, 2000). Based on phenotypic properties and DNA $\mathrm{G}+\mathrm{C}$ content, these organisms were tentatively identified as Bacillus species, closely related to Bacillus firmus, Brevibacillus laterosporus, Bacillus lentus and Paenibacillus polymyxa. To establish their correct taxonomic position and to rectify the tenuous classification, strains B. ${ }^{\mathrm{T}}$, B. 7 and B. 9 were further characterized by 16S rDNA sequencing. Data suggested that the strains B. $3^{\mathrm{T}}$, B.7 and B.9 could be a Paenibacillus species. After carefully studying the data obtained by phenotypic characterization, DNA G $+\mathrm{C}$ content, DNADNA relatedness and 16S rDNA analysis, a novel species, Paenibacillus jamilae sp. nov., is proposed.

\section{METHODS}

Bacterial strains and culture conditions. Strains B. $3^{\mathrm{T}}$, B.7 and B.9 were isolated from a sample of corn-compost treated with OMWW. The following reference strains were included in the study: Bacillus firmus CCM 2213 ${ }^{\mathrm{T}}$, Bacillus lentus CCM 2214 ${ }^{\mathrm{T}}$, Brevibacillus laterosporus CCM $2116^{\mathrm{T}}$ and $P$. polymyxa CECT 153. All strains were grown on YM broth (Difco) and 15 g agar (Difco) $1^{-1}$ (if needed). Strains B. $3^{\mathrm{T}}$, B.7 and B. 9 were cultivated at $30^{\circ} \mathrm{C}$ for $24 \mathrm{~h}$ on TSA (Difco) and TSB (Difco) supplemented with $0.5 \%(\mathrm{w} / \mathrm{v})$ glycine for the isolation of DNA.

Morphological and physiological tests. The morphology of cells, motility, shape of spores, swollen sporangia and parasporal crystal were examined by phase-contrast microscopy. The presence of EPS and size of the cells were examined by transmission electron microscopy using cells from a $48 \mathrm{~h}$ culture that were stained with $2.5 \%(\mathrm{v} / \mathrm{v})$ glutaraldehyde and $2 \%(\mathrm{v} / \mathrm{v})$ paraformaldehyde in a $0 \cdot 1 \mathrm{M}$ cacodylate-sodium salt buffer which contained $0.075 \%$ $(\mathrm{w} / \mathrm{v})$ ruthenium red. The grids were examined using a model Zeiss 902 transmission electron microscope. Catalase activity was determined by bubble production in a $10 \%$ (v/v) $\mathrm{H}_{2} \mathrm{O}_{2}$ solution. Oxidase activity was determined by oxidation of $1 \%(\mathrm{w} / \mathrm{v})$ tetramethyl-p-phenylenediamine. Utilization and production of gases by substrates as sole carbon source was performed with API 50CHB (bioMérieux) using $P$. polymyxa as control strain. The following characteristics were determined as previously described (Claus \& Berkeley, 1986): hydrolysis of gelatin, casein and starch; anaerobic growth; Voges-Proskauer; utilization of citrate and propionate; reduction of nitrate; production of

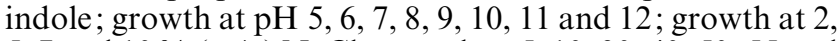
5,7 and $10 \%(\mathrm{w} / \mathrm{v}) \mathrm{NaCl}$; growth at 5, 10, 30, 40, 50, 55 and $65^{\circ} \mathrm{C}$; and growth in the presence of $0.001 \%(\mathrm{w} / \mathrm{v})$ lysozyme. Other tests were completed with API 20E (bioMérieux).

\section{Chemotaxonomic characterization}

Analysis of isoprenoid quinones. Isoprenoid quinones were extracted by treating $500 \mathrm{mg}$ lyophilized cells grown in YM broth with $150 \mathrm{ml}$ chloroform: methanol $(2: 1, \mathrm{v} / \mathrm{v})$ for $2 \mathrm{~h}$, using a reciprocal shaker (120 strokes $\left.\mathrm{min}^{-1}\right)$ at room temperature. The extracted solution was concentrated using liquid $\mathrm{N}_{2}$ and transferred by re-dissolving in acetone. The resulting solution was evaporated, separated by TLC using n-hexane:dimethyl ether $(85: 15, \mathrm{v} / \mathrm{v})$ as the solvent and recovered from TLC plates with acetone. Isoprenoid quinones thus obtained were analysed by HPLC (Waters) as described by Yumoto et al. (1998).

Analyses of cellular fatty acids and the cell wall. For cellular fatty acid analysis, cells were cultivated in YM broth until the late exponential phase of growth. Methods for fatty acid extraction, methyl ester preparation, methyl ester separation by GC and identification of fatty acids were previously described (Monteoliva-Sánchez et al., 1993).

Identification of meso-diaminopimelic acid in the cell wall was performed by TLC (DC-Alufoline Cellulose; Merck) as described by Yamada \& Komagata (1970).

Isolation of DNA and determination of $\mathbf{G}+\mathbf{C}$ content. Chromosomal DNA was isolated by the method of Marmur (1961). DNA preparations were analysed by electrophoresis through $0.8 \%(\mathrm{w} / \mathrm{v})$ agarose gel, spectrophotometrically quantified at $260 \mathrm{~nm}$ (Biophotometer-Eppendorf) and stored at $-20{ }^{\circ} \mathrm{C}$.

The $\mathrm{G}+\mathrm{C}$ content was determined by the method of Marmur \& Doty (1962), based on the determination of DNA $T_{\mathrm{m}}$ DNA from Escherichia coli was included in each set of analyses as a reference standard. The $\mathrm{G}+\mathrm{C}$ content of E. coli DNA was regarded as $51.7 \mathrm{~mol} \%$.

DNA-DNA reassociation and 165 rDNA sequencing. The hybridization of genomic DNA from strain B. $3^{\mathrm{T}}$ with B.7, B.9, Bacillus firmus, Bacillus lentus, Brevibacillus laterosporus and $P$. polymyxa was performed according to the method of Ziemke et al. (1998).

Purified genomic DNA was used for the amplification of $16 \mathrm{~S}$ rRNA genes via PCR with the forward primer 16F27 (5'AGAGTTTGATCMTGGCTCAG-3') and the reverse primer 16R1525 (5'-AAGGAGGTGWTCCARCC-3'). PCR reactions were carried out under the conditions described by Saiki et al. (1988). Amplification products were purified with Microcon-100 concentrators (Amicon) and directly sequenced using an Applied Biosystems 373A DNA sequencer and the manufacturer's protocols for Taq cyclesequencing with fluorescent dye-labelled dideoxynucleotides (Perkin-Elmer). The primers used for the sequencing reactions were previously described (Lane, 1991).

Phylogenetic analysis. To establish the relatives of strain B. $3^{\mathrm{T}}$ based on $16 \mathrm{~S}$ rDNA sequence similarity, preliminary searches in different databases were performed with the program BLAST. Sequences of close relatives (Paenibacillus) were retrieved from databases and were aligned with the sequences of other Bacillus, Lactobacillus, Alicyclobacillus, Aneurinibacillus, Virgibacillus, Brevibacillus, Amphibacillus, Halobacillus, Gracilibacillus and Coprobacillus species using 
CLUSTAL W software (Thompson et al., 1994). The 16S rDNA similarity values were calculated from the alignments. The evolutionary distances were calculated using the DNADIST program of PHYLIP 3.5 software package (Felsenstein, 1989) with the model of Jukes \& Cantor (1969). A phylogenetic tree was constructed using the FITCH program, which uses the least-squares algorithm of Fitch \& Margoliash (1967). The tree was drawn with TREEVIEW program (Page, 1996).

\section{RESULTS AND DISCUSSION}

\section{Morphological and physiological characteristics}

The cells of strains B. $3^{\mathrm{T}}$, B.7 and B.9 were rod-shaped measuring $0.5-1.2 \times 4.5-6.5 \mu \mathrm{m}$ after growing for $48 \mathrm{~h}$ at $30{ }^{\circ} \mathrm{C}$ and $\mathrm{pH} 7 \cdot 0$. They produced ellipsoidal spores

Table 1. Differentiation of strain B. $3^{\top}$ from closely related Paenibacillus species

Strains: 1, B. $3^{\mathrm{T}} ; 2, P$. polymyxa $; 3, P$. peoriae $; 4, P$. azotofixans. +, Positive; -, negative; v, variable; ND, not determined.

\begin{tabular}{|lcccc|}
\hline Characteristic & $\mathbf{1}$ & $\mathbf{2 *}$ & $\mathbf{3}^{*}$ & $\mathbf{4}$ \\
\hline Growth in 0.001\% lysozyme & + & $\mathrm{V}$ & + & - \\
Acid from: & & & & \\
$\quad$ Arabinose & + & + & + & - \\
Xylose & + & + & + & - \\
Glycerol & + & + & - & - \\
$\quad$ Trehalose & + & + & - & $\mathrm{ND}$ \\
$\quad$ Methyl $\beta$-xyloside & - & + & $\mathrm{ND}$ & $\mathrm{ND}$ \\
Gas from carbohydrate & - & + & + & + \\
Starch hydrolysis & + & + & + & - \\
Citrate utilization & - & + & - & - \\
Nitrate reduced to nitrite & + & + & + & - \\
Casein hydrolysis & + & + & + & - \\
G + C content (mol \%) & $40-43$ & $43-46$ & $45-47$ & $48-53$ \\
\hline
\end{tabular}

* Data from Montefusco et al. (1993). in swollen sporangia. Colonies were convex, mucoid and opaque. The colonies of strain B.7 were greater in size $(>4 \mathrm{~mm})$ than those of strains B.9 and B. $3^{\mathrm{T}}$ $(<4 \mathrm{~mm})$. All strains formed motile microcolonies while growing on wet agar plates. The strains were facultatively anaerobic, Gram-variable and motile by means of peritrichous flagella. Strains had catalase activity, but no oxidase activity. These strains did not grow in the presence of $5 \%(\mathrm{w} / \mathrm{v}) \mathrm{NaCl}$, which is the case with other Paenibacillus species (Shida et al., 1997a). Gelatin, casein and starch were hydrolysed. The optimum growth temperature was $30^{\circ} \mathrm{C}$, as it is for all Paenibacillus species except Paenibacillus macquariensis which has an optimum growth temperature of 20-23 ${ }^{\circ} \mathrm{C}$ (Shida et al., 1997a). The optimum $\mathrm{pH}$ for growth was $7 \cdot 0$, but it was able to grow in a wide range of $\mathrm{pH}$ (5-12). Members of the genus Paenibacillus grow optimally at the same $\mathrm{pH}$ (Shida et al., 1997a). The strains B. $3^{\mathrm{T}}$, B.7 and B.9 grew in $100 \%(\mathrm{v} / \mathrm{v})$ OMWW, which was an important phenotypic difference that distinguished our strains from other known Paenibacillus species. All the physiological and biochemical characteristic which are identical among the isolated B. $3^{\text {T }}$, B. 7 and B.9 are given below in the description of the novel species. Only strain B. $3^{\mathrm{T}}$ was positive for ONPG hydrolysis and results obtained for acid production from several carbohydrates showed that utilization of methyl $\alpha$-D-mannoside was positive only for strain B. $3^{\mathrm{T}}$, methyl $\alpha$-D-glucoside was positive for strains B. $3^{\mathrm{T}}$ and B.7, and utilization of both inulin and gentiobiose was positive for strains B.7 and B.9. Paenibacillus strain B. $3^{\mathrm{T}}$ can be differentiated from other related Paenibacillus species as shown in Table 1.

\section{Chemotaxonomic characteristics}

meso-Diaminopimelic acid was the diamino acid found in the cell-wall peptidoglycan of strains B. $3^{\mathrm{T}}$, B.7 and B.9. This diamino acid is common to the members of the genus Paenibacillus and to other aerobic endospore formers such as Bacillus, Sporolactobacillus and Amphi-

Table 2. G + C content, $16 \mathrm{~S}$ rDNA similarity and DNA-DNA hybridization data for some strains studied

\begin{tabular}{|lcccc|}
\hline Strain & $\begin{array}{c}\boldsymbol{T}_{\mathbf{m}} \\
\left({ }^{\circ} \mathbf{C}\right)\end{array}$ & $\begin{array}{c}\mathbf{G}+\mathbf{C} \text { content } \\
(\mathbf{m o l} \%)\end{array}$ & $\begin{array}{c}\text { 16S rDNA } \\
\text { similarity (\%) }\end{array}$ & $\begin{array}{c}\text { Hybridization to DNA } \\
\text { from B.3 }\end{array}$ \\
\hline B.3 (RBR; \%)
\end{tabular}

ND, Not determined. 


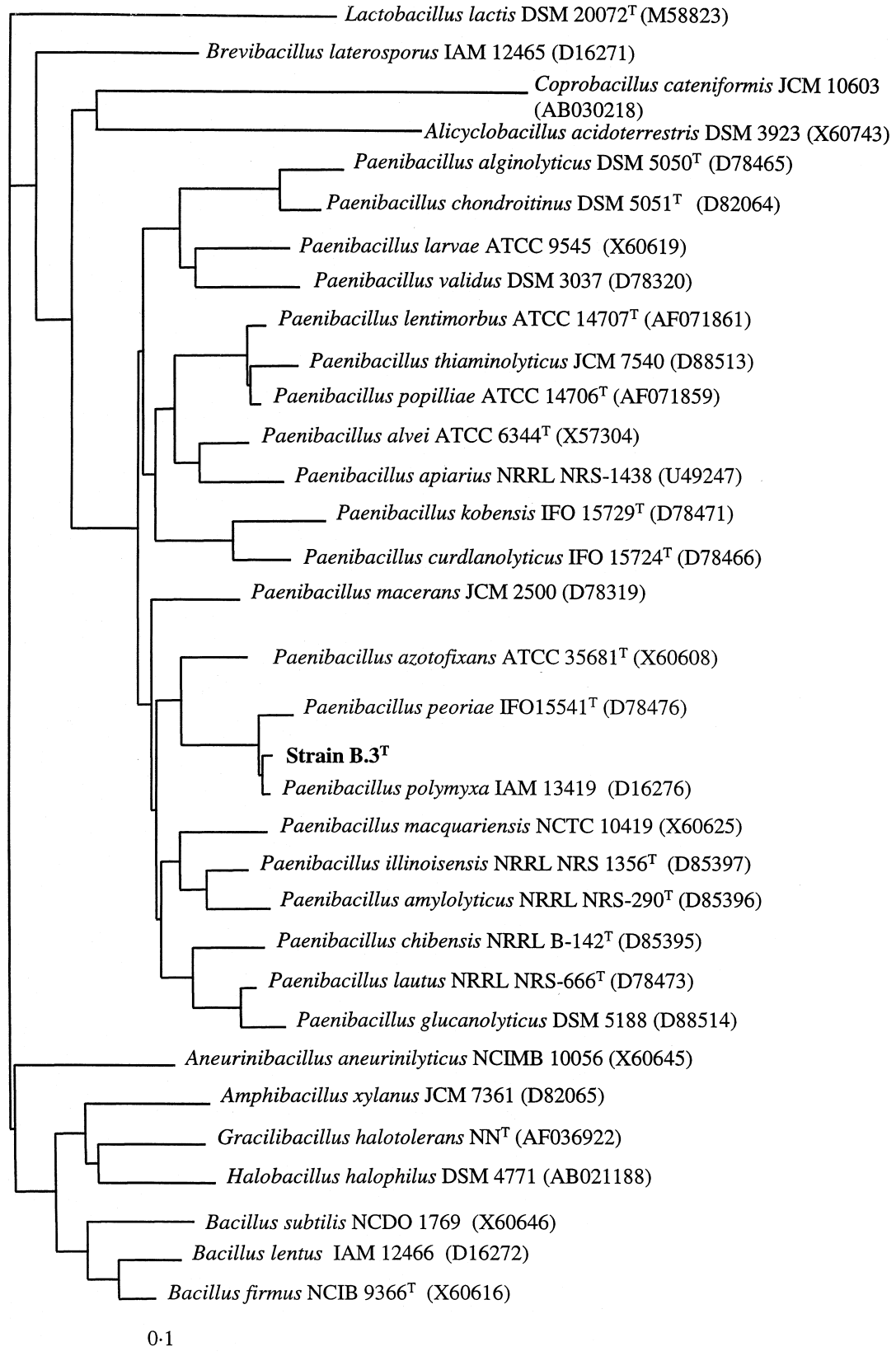

Fig. 1. Phylogenetic tree showing the position of strain B. $3^{\top}$ in relation to Paenibacillus species and some rod-shaped, endospore-forming bacteria based on $16 \mathrm{~S}$ rRNA gene sequences. EMBL accession numbers of reference sequences are given after the strain names. Bar, 1 nucleotide substitution per 10 nucleotides. bacillus (Shida et al., 1997a). The major isoprenoid quinone was MK-7, which is the major menaquinone generally found in aerobic, endospore-forming rods. Anteiso- $\mathrm{C}_{15: 0}$, the predominant fatty acid found in this genus (Shida et al., 1997a), was also the major fatty acids component of strains B. ${ }^{\mathrm{T}}$, B.7 and B.9.

\section{DNA base composition and DNA-DNA reassociation}

The $\mathrm{G}+\mathrm{C}$ contents of strains B. $3^{\mathrm{T}}$, B. 7 and B.9 were $40 \cdot 6,40 \cdot 7$ and $40 \cdot 8 \mathrm{~mol} \%$, respectively. These $\mathrm{G}+\mathrm{C}$ contents lie within the range found in the members of genus Paenibacillus (Shida et al., 1997a). DNA G + C contents of Bacillus firmus, Bacillus lentus, Brevibacillus laterosporus and P. polymyxa, Paenibacillus peoriae, Paenibacillus azotofixans and their relative binding ratios (RBRs) of DNA-DNA hybridization are compiled in Table 2. Strains B.3 ${ }^{\mathrm{T}}$, B.7 and B.9 belonged to the same species because their RBRs to each other were $>70 \%$. However, it was concluded that these strains were a separate species from Bacillus firmus, Brevibacillus laterosporus, Bacillus lentus and Paenibacillus polymyxa because the RBRs with these species were $<22 \%$.

\section{Phylogenetic analysis}

Although the preceding biochemical, chemotaxonomic, $\mathrm{G}+\mathrm{C}$ content and hybridization analysis did not establish a definite taxonomic position for the 
strains B. $3^{\mathrm{T}}$, B.7 and B.9, these data suggested Paenibacillus as a possible classification. 16S rDNA was sequenced to verify the suggestion. An almost complete $16 \mathrm{~S}$ rDNA sequence $(1525 \mathrm{bp})$ of strain B. $3^{\mathrm{T}}$, which corresponded to a region between positions 1 and 1524 by comparison with other eubacteria $16 \mathrm{~S}$ rRNA genes, was obtained. The phylogenetic tree (Fig. 1) constructed from the sequence data showed that strain B. $3^{\mathrm{T}}$ appeared within the evolutionary radiation encompassing genus Paenibacillus and occupied a distinct phylogenetic position within the genus. The phylogenetic study clearly established that our strains were a Paenibacillus species. Moreover, there was a consensus signature sequence (PAEN515F) of Paenibacillus genus (5'-GAGTAACTGCTACAAGAGTGACGGTACCTGAGAAGAAAGCCCC-3') within the 16S rRNA sequence of our strains (Shida et al., 1997a).

The results of this polyphasic study supports strains B. $3^{\mathrm{T}}$, B. 7 and B.9 being the same species and belonging to the genus Paenibacillus. Their genetic distinctiveness inferred from the phylogenetic study warrants the proposal of these strains as a novel species, Paenibacillus jamilae sp. nov.

\section{Description of Paenibacillus jamilae sp. nov.}

Paenibacillus jamilae (ja.mi'lae. N.L. fem. n. jamilae residual water of olive oil production, from jamila specific term of Arabic origin commonly used in Andalusia, Spain).

Cells are rod-shaped $(0 \cdot 5-1.2 \times 4.5-6 \cdot 5 \mu \mathrm{m})$ and motile by means of peritrichous flagella. Ellipsoidal spores are formed in swollen sporangia. Colonies are convex, mucoid and opaque. Forms motile microcolonies on wet agar plates. Facultatively anaerobic and Gramvariable. Catalase reaction is positive, whereas oxidase activity is negative. Gelatin, casein and starch are hydrolysed. Acid but not gas is produced from glycerol, L-arabinose, ribose, D-xylose, galactose, Dglucose, D-fructose, D-mannose, D-mannitol, amygdalin, arbutin, aesculin, salicin, cellobiose, maltose, lactose, melibiose, sucrose, trehalose, raffinose, glycogen and D-turanose. Erythritol, D-arabinose, Lxylose, adonitol, methyl $\beta$-xyloside, L-sorbose, rhamnose, dulcitol, inositol, sorbitol, $N$-acetylglucosamine, melezitose, xylitol, D-lyxose, D-tagatose, D-fucose, Darabitol, L-arabitol, gluconate, 2-keto-gluconate and 5-keto-gluconate are not utilized as sole carbon sources. Citrate and propionate are not utilized. Acetylmethylcarbinol is positive (as determined by the Voges-Proskauer reaction). Nitrate is reduced to nitrite. Growth occurs at temperatures of $30-40{ }^{\circ} \mathrm{C}$ and at pH $5-12$. Optimum growth occurs at $30^{\circ} \mathrm{C}$ and at $\mathrm{pH} 7 \cdot 0$. Growth occurs in the presence of $2 \% \mathrm{NaCl}$ and $0.001 \%$ lysozyme, whereas it is inhibited by $5 \%$ $\mathrm{NaCl}$. The major fatty acid is anteiso- $\mathrm{C}_{15: 0}$. The major quinone is $\mathrm{MK}-7$. The mean DNA $\mathrm{G}+\mathrm{C}$ content is $40 \cdot 6-40 \cdot 8 \mathrm{~mol} \%$. The type strain is $\mathrm{B} .3^{\mathrm{T}}(=\mathrm{CECT}$ $5266^{\mathrm{T}}=$ DSM $\left.13815^{\mathrm{T}}\right)$.

\section{ACKNOWLEDGEMENTS}

The authors would like to thank Dr Antonio Lario (Institute of Parasitology and Biomedicine Lopez-Neyra) for his help with DNA sequencing, and the Technical Services of University of Granada for its help with electron microscopy. This research was supported by a grant from the Ministerio de Educación y Ciencia, Spain (Project no. OLI96-2189).

\section{REFERENCES}

Ash, C., Priest, F. G. \& Collins, M. D. (1993). Molecular identification or rRNA group 3 bacilli (Ash, Wallbanks and Collins) using a PCR probe test. Antonie Leeuwenhoek 64, 253-260.

Claus, D. \& Berkeley, R. C. W. (1986). Genus Bacillus Cohn 1872, $174^{\mathrm{AL}}$. In Bergey's Manual of Systematic Bacteriology, vol. 2, pp. 1105-1139. Edited by P. H. A. Sneath, N. S. Mair, M. E. Sharpe \& J. G. Holt. Baltimore: Williams \& Wilkins.

Felsenstein, J. (1989). PHYLIP - Phylogeny inference package (version 3.2). Cladistics 5, 164-166.

Fitch, W. M. \& Margoliash, E. (1967). Construction of phylogenetic trees: a method based on mutation distances as estimated from cytochrome $c$ sequences is of general applicability. Science 155, 279-284.

Jukes, T. H. \& Cantor, C. R. (1969). Evolution of protein molecules. In Mammalian Protein Metabolism, vol. 3, pp. 21-132. Edited by H. N. Munro. New York: Academic Press.

Kageyama, A. \& Benno, Y. (2000). Coprobacillus catenaformis gen. nov., sp. nov., a new genus and species isolated from human faeces. Microbiol Immunol 44, 23-28.

Lane, D. J. (1991). 16S/23S rRNA sequencing. In Nucleic Acid Techniques in Bacterial Systematics, pp. 115-175. Edited by E. Stackebrandt \& M. Goodfellow. Chichester: John Wiley.

Marmur, J. (1961). A procedure for the isolation of deoxyribonucleic acid from microorganisms. J Mol Biol 3, 208-218.

Marmur, J. \& Doty, P. (1962). Determination of the base composition of deoxyribonucleic acid from its thermal denaturation temperature. J Mol Biol 4, 109-118.

Montefusco, A., Nakamura, L. K. \& Labeda, D. P. (1993). Bacillus peoriae sp. nov. Int J Syst Bacteriol 43, 388-390.

Monteoliva-Sánchez, M., Ramos-Cormenzana, A. \& Russell, N. J. (1993). The effect of salinity and compatible solutes on the biosynthesis of cyclopropane fatty acids in Pseudomonas halosaccharolytica. J Gen Microbiol 139, 1877-1884.

Nakamura, L. K. (1996). Paenibacillus apiarius sp. nov. Int J Syst Bacteriol 46, 688-693.

Page, R. D. M. (1996). TREEVIEW: an application to display phylogenetic trees on personal computers. Comput Appl Biosci 12, 357-358.

Priest, F. G. (1981). DNA homology in the genus Bacillus. In The Aerobic Endospore-forming Bacteria, pp. 33-57. Edited by R. C. W. Berkeley \& M. Goodfellow. London: Academic Press.

Ramos-Cormenzana, A. \& Monteoliva-Sánchez, M. (2000). Biopharmaceutical potential of olive industrial wastes. ARS Pharm 41, 129-136 (in Spanish).

Ramos-Cormenzana, A., Monteoliva Sánchez, M. \& López, M. J. (1995). Bioremediation of alpechín. Int Biodeterior Biodegrad 35, 249-268.

Saiki, R. K., Gelfand, D. H., Stoffel, S., Scharf, S. J., Higuchi, R., Horn, G. T., Mullis, K. B. \& Erlich, H. A. (1988). Primer-directed enzymatic amplification of DNA with a thermostable DNA polymerase. Science 239, 487-491. 
Shida, O., Takagi, H., Kadowaki, K. \& Komagata, K. (1996). Proposal for two new genera. Brevibacillus gen. nov. and Aneurinibacillus gen. nov. Int J Syst Bacteriol 46, 939-946.

Shida, O., Takagi, H., Kadowaki, K., Nakamura, L. K. \& Komagata, K. (1997a). Transfer of Bacillus alginolyticus, Bacillus chondroitinus, Bacillus curdlanolyticus, Bacillus glucanolyticus, Bacillus kobensis and Bacillus thiaminolyticus to the genus Paenibacillus and emended description of the genus Paenibacillus. Int J Syst Bacteriol 47, 289-298.

Shida, O., Takagi, H., Kadowaki, K., Nakamura, L. K. \& Komagata, K. (1997b). Emended description of Paenibacillus amylolyticus and description of Paenibacillus illinoisensis sp. nov. and Paenibacillus chibensis sp. nov. Int J Syst Bacteriol 47, 299-306.

Slepecky, R. A. \& Hemphill, H. E. (1991). The genus Bacillusnonmedical. In The Prokaryotes, pp. 1663-1696. Edited by A. Balows, H. G. Trüper, M. Dworkin, W. Harder \& K.-H. Schleifer. New York: Springer.

Spring, S., Ludwig, W., Marquez, M. C., Ventosa, A. \& Schleifer, K.-H. (1996). Halobacillus gen. nov., with description of Halobacillus litoralis sp. nov. and Halobacillus truperi sp. nov., and transfer of Sporosarcina halophilia to Halobacillus halophilus comb. nov. Int J Syst Bacteriol 46, 492-496.

Stackebrandt, E. \& Liesack, W. (1993). Nucleic acids and classification. In Handbook of New Bacterial Systematics, pp. 152-189. Edited by M. Goodfellow \& A. G. O’Donnell. London: Academic Press.

Thompson, J. D., Higgins, D. G. \& Gibson, T. J. (1994). CLUSTAL $\mathrm{W}$ : improving the sensitivity of progressive multiple sequence alignment through sequence weighting, position-specific gap penalties and weight matrix choice. Nucleic Acids Res 22, 4673-4680.

Wainø, M., Tindall, B. J., Schumann, P. \& Ingvorsen, K. (1999). Gracilibacillus gen. nov., with description of Gracilibacillus halotolerans gen. nov., sp. nov.; transfer of Bacillus dipsosauri to Gracilibacillus dipsosauri comb. nov., and Bacillus salexigens to the genus Salibacillus gen. nov., as Salibacillus salexigens comb. nov. Int J Syst Bacteriol 49, 821-831.

Wisotzkey, J. D., Jurtshuk, P., Jr, Fox, G. E., Deinhard, G. \& Poralla, K. (1992). Comparative sequence analyses on the $16 \mathrm{~S}$ rRNA (rDNA) of Bacillus acidocaldarius, Bacillus acidoterrestris, and Bacillus cycloheptanicus and proposal for creation of a new genus, Alicyclobacillus gen. nov. Int J Syst Bacteriol 42, 263-269.

Yamada, K. \& Komagata, K. (1970). Taxonomic studies on coryneform bacteria. II. Principal amino acids in the cell wall and their taxonomic significance. J Gen Appl Microbiol 16, 103-113.

Yumoto, I., Yamazaki, K., Sawabe, T., Nakano, K., Kawasaki, K., Ezura, Y. \& Shinano, H. (1998). Bacillus horti sp. nov., a new Gram-negative alkaliphilic bacillus. Int J Syst Bacteriol 48, 565-571.

Ziemke, F., Höfle, M. G., Lalucat, J. \& Rosselló-Mora, R. (1998). Reclassification of Shewanella putrefaciens Owen's genomic group II as Shewanella baltica sp. nov. Int J Syst Bacteriol 48 , 179-186. 